\title{
Civic, ethnic, hybrid and atomised identities in Central and Eastern Europe
}

\section{Victor Cebotari}

To cite this article: Victor Cebotari (2016) Civic, ethnic, hybrid and atomised identities in Central and Eastern Europe, Identities, 23:6, 648-666, DOI: 10.1080/1070289X.2015.1059338

To link to this article: http://dx.doi.org/10.1080/1070289X.2015.1059338

\section{曲 Published online: 24 Jun 2015.}

Submit your article to this journal $\pi$

LII Article views: 479

Q View related articles $\sqsubset$

View Crossmark data $\asymp$ 


\title{
Civic, ethnic, hybrid and atomised identities in Central and Eastern Europe
}

\author{
Victor Cebotari
}

(Received 28 November 2013; final version received 5 March 2015)

\begin{abstract}
While the topic of identity of ethnic minorities abounds in theoretical insights, most discussion is still clustered around the civic-ethnic divide while assuming conclusions with limited empirical evidence. By contrast, this article uses a four-category typology of identity that considers both ingroup and out-group attachments to address hypotheses about competing identities and about factors influencing minorities to adopt one identity type over others. Based on unique data evidence of 12 ethnic minorities in Central and Eastern Europe, this study concludes that the 'hybrid' identity, rather than the literature-assumed 'ethnic' identity, tops the identification preference of minorities, although there are differences in levels and patterns when controlling for various covariates. The choice of identity depends on the socialisation process, the economic status, the perceived discrimination and intergroup tensions, reflecting variations in the system of values common to a region with complex ethnic dynamics.
\end{abstract}

Keywords: ethnic identity; civic identity; hybrid identity; atomised identity; ethnic minorities; Central and Eastern Europe

\section{Introduction}

The concept of identity is currently intensely debated in Europe. Scholars advance theories explaining social processes by which group belonging impacts feelings of identity but pay significantly less attention to the development of multiple, overlapping identities. The number and the intensities of multiple identities which ethnic minorities may adopt are informative of a society's levels of social cohesion (Leach et al. 2008). Minorities that feel closely involved with the national realm of the hosting country are seen as a barometer for cohesion (Parekh 2000) and as proof that the multicultural project works (Kymlicka 2001).

Meanwhile, in Central and Eastern Europe (CEE), the collapse of the communist bloc brought profound changes in the way minorities identify themselves. With transition, the social stratification based on ideological grounds had disappeared, leaving identities prone to arise, develop and sometimes rage in extremis. The transformation and the creation of new state structures, the formation of ethnic autonomies and European Union enlargement have impacted the system of identity of many minorities in CEE. Additionally, some national 
identity structures in the region are believed to be 'political' and 'defined by the state', leading to an 'ethnic definition of nationality' (Korostelina 2003, 141). This context brings anxiety to those individuals who do not subscribe to identities that do not match the sole national or ethnic system of values of the host nation. A question thus arises as to the nature of identities being adopted by minorities and as to the characteristics of those who claim ethnic, national or mixed identities in CEE countries.

Despite the claims made about identification of minorities, the complexity of this phenomenon has scarcely been tested in the region (Shulman 2002a, 554). The existing scholarship in this area of study is largely descriptive, normative, one-dimensional, mainly based on single case studies and lacks a strong empirical base (Brown 2000). As Huddy (2001, 128) points out: 'researchers ... have been slow to incorporate the concept of identity into their empirical studies'.

Building on these limitations, this article aims to differentiate between ethnic and national closeness and to compare how the mix of these values is distributed across individuals of 12 minorities in CEE. ${ }^{1}$ This study builds on the previous work of Hansen and Hesli (2009), who widened the identity typology to encompass four values: civic, ethnic, hybrid and atomised identities. Unlike Hansen and Hesli (2009) who based their evidence on Ukrainian ethnic minorities only, the current study goes beyond the contextual evidence of a single country and tests the interplay of different identities for a larger number of ethnic minorities in CEE. The argument of this study is that the salience of national, ethnic and mixed identities in the national context of a hosting nation depends on the development of cleavage structures such as discrimination, intergroup tensions, socialisation effects and democratisation. This article captures the variation of different identities by using data at the individual level while including a comparative angle at the group level. An analysis of identity attitudes at the individual level brings the advantage of a more accurate assessment of diversity and the avoidance of what Brubaker $(2004,8)$ calls 'groupism', the tendency to assume that minority groups are 'internally homogeneous, externally bounded'.

\section{Conceptualising identity}

There is a large number of studies on the trade-off between national and ethnic identification and the effects this dichotomy has on the host society (Huddy 2001; Korostelina 2003; Kymlicka 2000; Platt 2014). In the early days, Kohn (1944, 329) made the distinction between western 'civic' and eastern 'ethnographic' types of nationalism. Later on, Smith $(1991,11)$ nuanced this distinction as 'civic' and 'ethnic' nationalism. Others distinguished between a 'nationality' which is based on the liberal and tolerant values of the West and the 'nationalism' of the East which is more destructive and intolerant (Miller 1995, 11). The general assumption is that western nationalism is the result of the 
nation-formation process in which the consolidation of the state transformed residents of all ethnic backgrounds into one 'nation'. The ethnic nationalism of the East, on the other hand, has been created against the existing states, by redrawing state boundaries to accommodate ethnographic differences in highly heterogeneous societies (Sekulic 2004, 459). According to Schopflin (1996), Eastern European elites mobilised people around ethnic rather than civic values in the process of shaping states from the dominant empires. This process left the region vulnerable to failed assimilation attempts, interethnic violence and state disruptions. Furthermore, Schopflin $(1996,153)$ holds communism responsible for transforming CEE countries into 'civic deserts', characterised by mistrust and atomisation. In such environments, only ethnic identities could survive more or less intact (Schopflin 1995, 53).

The East-West divide can be amended nevertheless. There are cases in Western Europe that express elements of eastern nationalism - Irish or Basque movements for example. Similarly, there are cases in the East with elements of the West - Hungarian or Polish nationalism for instance. To a certain extent, these cases testify to the need to revise the West-East and civic-ethnic distinctions in order to better respond to current trends in the development of identity values in Europe.

In line with social identity theory, individuals prefer memberships in social groups and their in-group identification often results in negative evaluations of out-group members (Hogg 2001). At the same time, scholars have raised doubts whether in-group attachment fuels hostility to 'others' (Oliver and Wong 2003) and whether the civic-ethnic dichotomy fully captures the entire range of identities individuals may adopt (Brown 2000). Janmaat (2006) shows that individuals avoid the civic-ethnic divide and see identity in terms of political, cultural and ethnic dimensions which do not compete with national values. Moreover, the broad assimilation theory (Alba and Nee 2003) points to the convergence of identities when minorities gradually adopt more 'symbolic' forms of ethnic identity (Gans 1979), while at the same time increasing their identification with the majority group. Yet, identity assimilation is rarely a complementary process in which minority identity decreases and the majority attachment increases. It is rather an asymmetrical process which sometimes interrelates but rarely matches the two axes of attachment (Berry 1997).

It is therefore important to emphasise not only the classical distinction between civic and ethnic identities but also to zoom in on the different forms of individual attachment when civic and ethnic identities coalesce. According to Shulman (2002a), civic and ethnic identities are ideal categories, but in reality most dynamics combine elements of both. Therefore, there are two elements to be inferred when capturing variations in individual attachment: first, identity varies in the way minorities feel in relation to their ethnic group; and second, identity varies in the degree of closeness minorities feel in relation to their hosting nation. According to Hansen and Hesli (2009), when the two elements are combined, four identity dimensions emerge: (1) a civic identity 
(Hansen and Hesli 2009; Sekulic 2004), also called an assimilated identity (Phinney et al. 2001), materialises when individuals feel closer to the hosting nation and more distant from the ethnic group. Civic identity responds well to stimuli such as political will, democracy, rule of law and strong institutions - all common factors that bring people with different ethnic backgrounds together. Traditionally, it was believed that civic identity is a primary characteristic of the West (Kohn 1944). (2) An ethnic (Hansen and Hesli 2009; Schopflin 1996) or separated identity (Phinney et al. 2001) emerges when individuals feel strongly attached to their ethnic groups, and weakly identified with the national values of the hosting state. Ethnic identity is fuelled by perceptions of a common descent and belonging to one people (Smith 1991). The target of ethnic identity is the promotion of ethnic group values, sometimes at the expense of other groups in society (Ignatieff 1993). The conventional wisdom associates ethnic attachment with the East, though recent studies show weaker patterns of ethnic identity among CEE minorities (Shulman 2002a). (3) The hybrid (Hansen and Hesli 2009), also known as integrated (or bicultural) identity (Phinney et al. 2001), exposes strong ethnic and national attachments with the host nation. Brubaker (1996) mentions the hybrid identity as likely in states with strong core nations, where minority rights are respected and no forced assimilation attempts occur. Moreover, the hybridisation of identities was found to be fuelled by globalisation and democratisation (Anthias 2001), two events that make minorities feel integrated while accepting the heterogeneous nature of their hosting nation. The existing studies make it difficult to predict the incidence of hybrid identity in CEE: scholarship points to low rates of hybrid identity (Hansen and Hesli 2009) while others to high levels of hybridisation (Cieslik and Verkuyten 2006) in the region. And (4) the atomisation of individuals is part of the communist legacy in CEE (Shulman 2002a, 557). Atomised (Bahry et al. 2005; Hansen and Hesli 2009) or marginalised identity (Phinney et al. 2001) characterises individuals with negative feelings towards their ethnic and national belonging. In general, atomised individuals are often misrepresented in the measurements of identity in CEE (Hansen and Hesli 2009).

From this discussion, several implications emerge. In line with the civic/ West-ethnic/East divide, it is expected that ethnic identity would secure a significant share of attachment among minorities in CEE. Given the communist legacy in the region, the proportion of atomised identity is expected to be noteworthy. At the same time, the proportions of civic and hybrid identities may be high as well, given the substantial progress in transition to democracy many countries have achieved in the region. This study nevertheless expects to find a substantial variation across the 12 minorities, reflecting the different contexts in which identities mingled and evolved over time. Additionally, it is important to observe the effects of impact factors on the distribution of identities. Specifically, the following questions are addressed: 
(1) What is the distribution of ethnic, civic, hybrid and atomised identities within and across 12 ethnic minorities in CEE?

(2) What factors impact different identities? How do different identities connect with people's characteristics, values and attitudes?

\section{Data and measures}

This study uses the European National and Regional Identities - A Value and Identity Survey (ENRI-VIS), a unique data set collected in 2010 among 12 ethnic minorities in CEE. The sample of ENRI-VIS comprises 6839 cases. The sampled population includes members of ethnic minorities who see themselves as belonging to that specific minority in the country. Thus, ENRI-VIS applies a subjective sense of ethnic membership which is independent of the citizenship of the country where the survey took place. The sampled individuals are 18 years or older and were living in the country for at least one year at the time of the survey.

Three sampling methods were used to collect data: (1) snowball sampling strategies were applied in settlements where minorities account for less than $10 \%$ of the total population; (2) random route sampling (RRS), boosted with additional focused enumeration, was used in locations where minorities represent between $10 \%$ and $30 \%$ of the total population; and (3) proportional RRS was applied in settlements where minorities form compact communities with more than a $30 \%$ share in the total population.

Some limitations must be mentioned in connection to the measurements of identity. The idiom of identity is highly contextual and group-specific and it makes identity questions sensitive to interpretation biases. Hence, special attention was given to translating the questionnaires into the language of the minority group and into the official language of the country. To assure standardisation, local experts in identity studies were asked to review all translations so that the meaning of identity questions stayed the same and fitted the local context. During the survey, respondents were given the choice of using the language version of the questionnaire they were most comfortable with. The questionnaire also used a set of controls to account for the robustness of the main measurements in the data. Nevertheless, some uncertainty remains with respect to accounting for all possible caveats that might have an impact on identity measurements.

\section{Dependent variable}

This study uses the combined value of two indicators: one indicator measures individuals' ethnic group attachment and it is operationalised by the question, 'How close do you feel to [ethnic minority group]?'; the second indicator assesses minorities' closeness to the national realm of the host nation which is operationalised by the question, 'How close do you feel to [hosting country]?'. The latter indicator is suitable for measuring supra-group values, such as civic identity, because it captures, to a certain extent, the identification with the ethnic 
majority and thus with the out-group in the country. Each question is coded to a four-point scale of not close at all, not very close, rather close and very close. The scales were further recoded to binary versions of not very or not close at all as opposed to rather or very close feelings. This study uses ethnic and national attachments for measuring identity as justified by Connor (1994), who points to ethnic and national closeness as largely rooted in the psychological realm of individuals, rather than using static conditions such as language, religion, territory or race.

After respondents have been coded in relation to their ethnic and national attachment, the two dimensions are combined as follows: individuals with close ethnic feelings but distant from the national values of the host nation are coded with ethnic identity; individuals more attached to the hosting nation as compared to their ethnicity are coded with civic identity; respondents with close feelings towards both ethnic and national values are coded with hybrid identity; finally, respondents with weak ethnic and national feelings were coded with atomised identity.

\section{Independent variables}

Measuring multiple identities is at the core of understanding the challenges of the nation-building process. Among others, social factors were found to trigger identity feelings (Anderson 1991). Previous scholarship has pointed to language as an important socialisation factor in the shaping of identity feelings (Fishman 1980; Fournier 2002; Laitin 2000). Language is operationalised in this study by how often minorities speak at home either (1) the ethnic minority language; (2) bilingual: both the ethnic and national languages; (3) the national language of the country or (4) other language(s). The language in which minorities communicate captures 'the degree of cultural difference between ethnic groups' (Laitin $2000,143)$. Hence, the expectation is that those who regularly use the language of the host nation or are bilingual would show stronger civic and hybrid identities. On the other hand, it is expected that minorities who often communicate in the ethnic minority language are more likely to exhibit an ethnic or atomised identity.

Research points to socio-economic factors and their impact on self-esteem and collective identification (Katz 1940). Horowitz $(2000,186)$ further notes that individual and collective esteem is 'achieved through social recognition'. This means that individuals with a higher socio-economic status are better integrated among their ethnic kin, are more likely to be involved in its leadership and in community projects and would therefore show a stronger attachment to ethnic group values (Shulman 2002b). At the same time, it was found that people with higher socio-economic status tend to be more educated and more likely to adopt postmodern attitudes, making them less attached to ethnic primordial values (Inglehart 1997). Two measures for socio-economic status are employed in this analysis: (1) self-rated social standing and (2) employment status. For self-rated 
social standing, respondents are asked to position themselves on a 10-point Likert scale, where the top indicates high social standing and the bottom indicates low social standing. ${ }^{2}$ This scale was re-coded in a binary way with 5 being the cut-off point. The employment status records individuals who are (1) employed, (2) unemployed or (3) inactive (retired, pensioners, housewives, etc.). It is expected that individuals with a problematic socio-economic status such as being unemployed, inactive or with a low self-rated social standing are more likely to present ethnic or atomised identifications.

The practice of discrimination based on ethnic grounds was found to lead minorities to tighten their attachment around ethnic values and to feel less affection to the hosting nation (Harff and Gurr 2004; Verkuyten 2008). This study uses a binary indicator to measure discrimination, where 1 records the discrimination felt by individuals on ethnic or national grounds and 0 accounts for no discrimination. Individuals who experienced discrimination are expected to exhibit more ethnic or atomised identities and less civic or hybrid identities.

The literature usually assumes but rarely tests the impact of minority-majority tensions on the development of identity. Studies acknowledge that majority groups in former communist states have the tendency to monopolise their entitlement over national values which results in reactions from minorities (Coppieters 1998). When tensions arise, minorities usually adopt a protective ethnic attachment and tend to neglect national feelings for the host nation (Lam and Smith 2009). This study measures minority-majority tensions by using a binary indicator which records the tension, as perceived by respondents, between their own minority group and the respective majority group in the country. Individuals who report the existence of minority-majority tensions are expected to show higher levels of ethnic or atomised identity and lower levels of civic or hybrid attachment.

When approaching the concept of identity, Shulman $(2002 \mathrm{~b}, 5)$ considers demography as essential for understanding the distribution of attachment feelings. Different age cohorts in CEE are exposed to elite discourses at different times, and this impacts on the salience of competing identities across generations (Laitin 1998). Younger individuals, who are more exposed to postmodernist values (Inglehart 1997), are expected to hold more civic and hybrid identities than middle-aged and old-aged individuals. The impact of education on identity formation is well documented. More educated individuals were found to exhibit cosmopolitan feelings (Inglehart 1997) and likely to embrace out-group values (Bobo and Licari 1989). Yet, some exceptions to these links were also noted (Hansen and Hesli 2009; Sekulic 2004). Individuals with higher education are expected to broaden their identity norms by adopting more favourable attitudes towards civic and hybrid identities. Smith (1991) points to gender as important in explaining overlapping identities. Scholars hint that women are more trusting and less ethnocentric when adopting identity feelings compared to men (Scheepers, Felling, and Peters 1992). Yet, although associations were assumed, the link 
between gender and various identities has not been empirically tested in the literature.

\section{Analytical strategy}

The study performs both descriptive and inferential data analyses. Multinomial logistic regressions with applied marginal effects are used to test the impact of independent measures on civic, ethnic, hybrid and atomised identities, with separate computations for each identity category. The marginal effects are computed at the mean after the multinomial logistic regressions have been performed.

Two multinomial logistic regression models are employed. The first model tests the impact of demographics, language, socio-economic factors, discrimination and minority-majority tensions on identity categories. The second model adds the 12 ethnic minorities to the explanatory side.

All indicators were tested for multicollinearity and none was detected: the variation inflation factors are normal (1.0-1.2), and so are the tolerance values (0.7-0.9) (Weisberg 2005).

\section{Results: what is the distribution of ethnic, civic hybrid and atomised identities within and across minorities in CEE?}

This section looks at the dispersion of ethnic, civic, hybrid and atomised identities within and across 12 ethnic minority groups in CEE. The distribution of identities by ethnic group is presented in Table 1. The evidence challenges, to a certain extent, previous studies by Schopflin (1996), Brubaker (1996) and Smith (1991), who were not inclined to believe that

Table 1. Identity categories by ethnic groups (\%).

\begin{tabular}{lccccc}
\hline Ethnic group & Civic & Ethnic & Hybrid & Atomized & $N$ \\
\hline Russians in Latvia & 9.6 & 12 & 70.4 & 8 & $781(100 \%)$ \\
Belarusians in Lithuania & 33 & 11 & 44 & 12 & $391(100 \%)$ \\
Russians in Lithuania & 14.5 & 12.6 & 67 & 5.9 & $785(100 \%)$ \\
Poles in Lithuania & 13.9 & 11.5 & 70.4 & 4.2 & $801(100 \%)$ \\
Hungarians in Ukraine & 3.6 & 16.4 & 79.2 & 0.8 & $361(100 \%)$ \\
Poles in Ukraine & 4.8 & 2.1 & 92.8 & 0.3 & $374(100 \%)$ \\
Belarusians in Poland & 9.9 & 0.8 & 88.5 & 0.8 & $394(100 \%)$ \\
Ukrainians in Poland & 12.2 & 2.3 & 83 & 2.5 & $394(100 \%)$ \\
Lithuanians in Russia & 17.6 & 15.8 & 58.3 & 8.3 & $386(100 \%)$ \\
Slovaks in Hungary & 5.2 & 1.2 & 92.6 & 1 & $404(100 \%)$ \\
Poles in Belarus & 11 & 3 & 84.2 & 1.8 & $736(100 \%)$ \\
Hungarians in Slovakia & 1.4 & 11.1 & 86.1 & 1.4 & $774(100 \%)$ \\
Average all groups & 11.4 & 8.3 & 76.4 & 3.9 & $6581(100 \%)$ \\
\hline
\end{tabular}


identities other than 'ethnic' had a chance to arise so soon after the collapse of the communist regimes in CEE. ${ }^{3}$ The dispersion of identities in the sample varies across categories and across ethnic groups. Based on descriptive evidence, without controlling for cofounders, the hybrid identity is found to top the preferences among respondents, followed by civic, ethnic and atomised identities. Civic identity comes second in the preferences but the rates differ widely across minorities. High civic rates are present among Belarusians in Lithuania (33\%), higher than Russians (14.5\%) and Poles $(13.9 \%)$ in the same country. Least likely to show civic attachment are Hungarians in Slovakia (1.4\%), Hungarians (3.6\%) and Poles (4.8\%) in Ukraine and Slovaks in Hungary (5.2\%). All minorities with low civic attachment have active histories of group grievances and poor relations with their respective central state authorities which may explain, to a certain extent, the poor civic commitment of these ethnic groups.

Among minorities, higher or lower rates of attachment to ethnic identity are not necessarily in counterbalance to higher or lower rates of civic identity. Minorities in the sample are found to exhibit low rates of both civic and ethnic identities (Poles in Ukraine and Slovaks in Hungary); relatively equal rates of both civic and ethnic identities (Russians in Latvia and Lithuania, Poles in Lithuania, Lithuanians in Russia); high civic and low ethnic identities (Belarusians in Lithuania and Poland, Ukrainians in Poland and Poles in Belarus); and high ethnic and low civic identities (Hungarians in Ukraine and Slovakia). The asymmetry between ethnic and civic identity is common and previously documented by scholars (Shulman 2002a). Overall, ethnic identity is more present among Hungarians in Ukraine (16.4\%) and Lithuanians in Russia $(15.8 \%)$ and almost absent among Belarusians in Poland (0.8\%) and Slovaks in Hungary (1.2\%).

Hybrid identity is widespread among minorities in CEE. With the exception of Belarusians in Lithuania (44\%), all other minorities have a large majority of respondents who identify with hybrid values. As far as the author is aware, this is the first study to empirically document the prevalence of the hybrid identity among a large number of minorities in CEE. ${ }^{4}$ This finding is potentially encouraging for analysts as it points to the establishment of what it is seen as a natural step towards multicultural values in a region which has made substantial progress towards democracy.

The atomised identity is the least common in the sample. Most groups present negligible proportions of atomisation, with only three groups showing sizable scores: Belarusians in Lithuania (12\%), Russians in Latvia (8\%) and Lithuanians in Russia (8.3\%). The low occurrence of atomisation is unexpected given the communist legacy of the region which is believed to be the main source of this identity (Shulman 2002a, 557). The advance of democratic standards in the region may explain why the atomised identity, a value with proven anti-democratic support (Hansen and Hesli 2009, 18), is on a downward path. 


\section{Results: the shape of different identities - how do different identities connect with people's characteristics, values and attitudes?}

The effects of the multinomial logistic regressions with applied marginal effects are presented in order to evaluate the variations in civic, ethnic, hybrid and atomised identities when controlled for confounders (Tables 3 and 4).

When looking at gender, after adjusting for confounders (Tables 3 and 4), the results show that women are more likely to adopt a hybrid identity while there is no significant evidence linking gender with ethnic or atomised identities. The relation between gender and identity is largely unobserved in empirical research. Scholars hint at the fact that cultural traits impact the way gender interplays with national or ethnic identities (Lam and Smith 2009). Stereotypes and the specific expectations placed on women (e.g. housewives, raising children) reduce their motivation, as well as their opportunities to understand the culture of their own ethnic group and that of others in the country (Ullah 1987). Yet, women were found to excel in trust and tolerance (Scheepers, Felling, and Peters 1992), values that fit well with the profile of the hybrid identity.

When comparing the three age cohorts, younger individuals present lower rates of civic, ethnic or atomised identities but higher rates of hybrid identity (Table 2). When controlling for confounders, youngsters ( $\leq 29$ years old) are found to be more likely to adopt civic, ethnic and atomised identities while they are less likely to rely on hybrid attachment (Tables 3 and 4). This finding contrasts with recent evidence that found less or no significant attachment of young individuals with ethnic, atomised or civic identities (Hansen and Hesli 2009; Platt 2014). In CEE, the state discourse dealing with ethnic diversity favoured both national and ethnic values in the path to integration, citizenship and the cultural inclusion of ethnic minorities. Therefore, it is encouraging to see younger and dynamic individuals attaching more weight to civic identity but it is surprising to see that they neglect hybrid values. Also, the significant reliance on atomised feelings by individuals in the youngest age cohort could just as readily signal the rejection of the national building project as promoted by the state.

Minorities, who mostly speak the national language of the hosting state or are bilingual, are more likely to adopt the civic identity and less likely to rely on ethnic identity (Tables 3 and 4). Moreover, individuals who are fluent in both national and ethnic languages are less likely to adopt an atomised identity. The use of bilingualism by ethnic minorities reflects integration, a long period of residence in society or intermarriage (Fournier 2002). All these characteristics bring tolerance and respect for diversity that ease the formation of supra-group attachments.

Civic and hybrid identities are more common among employed than unemployed people and among those with high self-rated social standings (Table 2). Consequently, ethnic and atomised identities are favoured by unemployed individuals and by those with low self-declared social standing. Regression results provide support for the postmodernist assumption of Inglehart (1997) and reveal 
Table 2. Distribution of civic, ethnic, hybrid and atomised identities within the main variables of interest $(\%)$.

\begin{tabular}{|c|c|c|c|c|c|c|}
\hline & $\begin{array}{l}\text { Civic: } \\
11.1\end{array}$ & $\begin{array}{l}\text { Ethnic: } \\
8.8\end{array}$ & $\begin{array}{l}\text { Hybrid: } \\
76\end{array}$ & $\begin{array}{l}\text { Atomised: } \\
4.1\end{array}$ & $\begin{array}{c}\text { Test } \\
\text { statistic }\end{array}$ & $\begin{array}{l}\text { Number of } \\
\text { respondents }\end{array}$ \\
\hline Gender & & & & & $12.3 * *$ & \\
\hline Male & 12.3 & 9.3 & 73.8 & 4.6 & & 2490 \\
\hline Female & 10.3 & 8.5 & 77.4 & 3.7 & & 4091 \\
\hline Age & & & & & $119.4 * * *$ & \\
\hline$\leq 29$ & 9.1 & 7 & 80.6 & 3.3 & & 3575 \\
\hline $30-49$ & 12 & 9.5 & 73.7 & 4.7 & & 2015 \\
\hline$\geq 50$ & 16.4 & 13.8 & 64.4 & 5.3 & & 953 \\
\hline Education & & & & & $60 * * *$ & \\
\hline Primary & 10.7 & 9.7 & 75.7 & 3.9 & & 4234 \\
\hline Secondary & 7.7 & 4.5 & 84.9 & 2.9 & & 849 \\
\hline Tertiary & 14 & 8.8 & 72.2 & 5 & & 1467 \\
\hline $\begin{array}{l}\text { Language most } \\
\text { spoken at home }\end{array}$ & & & & & $359.6^{* * *}$ & \\
\hline Ethnic & 6.1 & 12.3 & 77.3 & 4.3 & & 3163 \\
\hline $\begin{array}{l}\text { Bilingual: ethnic } \\
\text { and national }\end{array}$ & 9.2 & 5.5 & 83.4 & 1.9 & & 1340 \\
\hline National & 19.3 & 5 & 71.7 & 4 & & 1054 \\
\hline Other & 20.6 & 6.3 & 66.8 & 6.3 & & 1008 \\
\hline $\begin{array}{l}\text { Self-rated social } \\
\text { standing }\end{array}$ & & & & & 6.4 & \\
\hline Low & 10.6 & 9.3 & 75.8 & 4.3 & & 4508 \\
\hline High & 12.1 & 8.2 & 76.3 & 3.5 & & 1806 \\
\hline Employment & & & & & $76.1^{* * *}$ & \\
\hline Employed & 13.1 & 10.5 & 72.3 & 4.2 & & 3046 \\
\hline Unemployed & 11.7 & 11.2 & 71.1 & 6 & & 547 \\
\hline Inactive & 8.9 & 6.6 & 80.9 & 3.6 & & 2947 \\
\hline Discrimination & & & & & $157.5^{* * *}$ & \\
\hline No & 11.3 & 7.3 & 77.5 & 3.9 & & 5760 \\
\hline Yes & 9.8 & 21.5 & 63.4 & 5.7 & & 703 \\
\hline $\begin{array}{l}\text { Minority-majority } \\
\text { tensions }\end{array}$ & & & & & $89.7 * * *$ & \\
\hline No & 12.1 & 5.9 & 78.6 & 3.5 & & 3327 \\
\hline Yes & 10.2 & 12.3 & 72.8 & 4.7 & & 2921 \\
\hline
\end{tabular}

Notes: $\chi^{2}$ tests were used for all comparisons. ${ }^{*} p<0.05, * * p<0.01, * * * p<0.001$.

that a high social standing is positively associated with hybrid identification and negatively related with ethnic and atomised identities. Counter to our expectations, inactive individuals, among whom are many students and pensioners, are found to be more prone to show hybrid identities and less likely to adopt an ethnic identity. The latter finding suggests an aggregated effect on identity, captured by the access to education (students) and the tolerant apathy of inactive individuals (pensioners), which in some contexts have been found to expose neutral feelings of identity (Hansen and Hesli 2009; Platt 2014). 


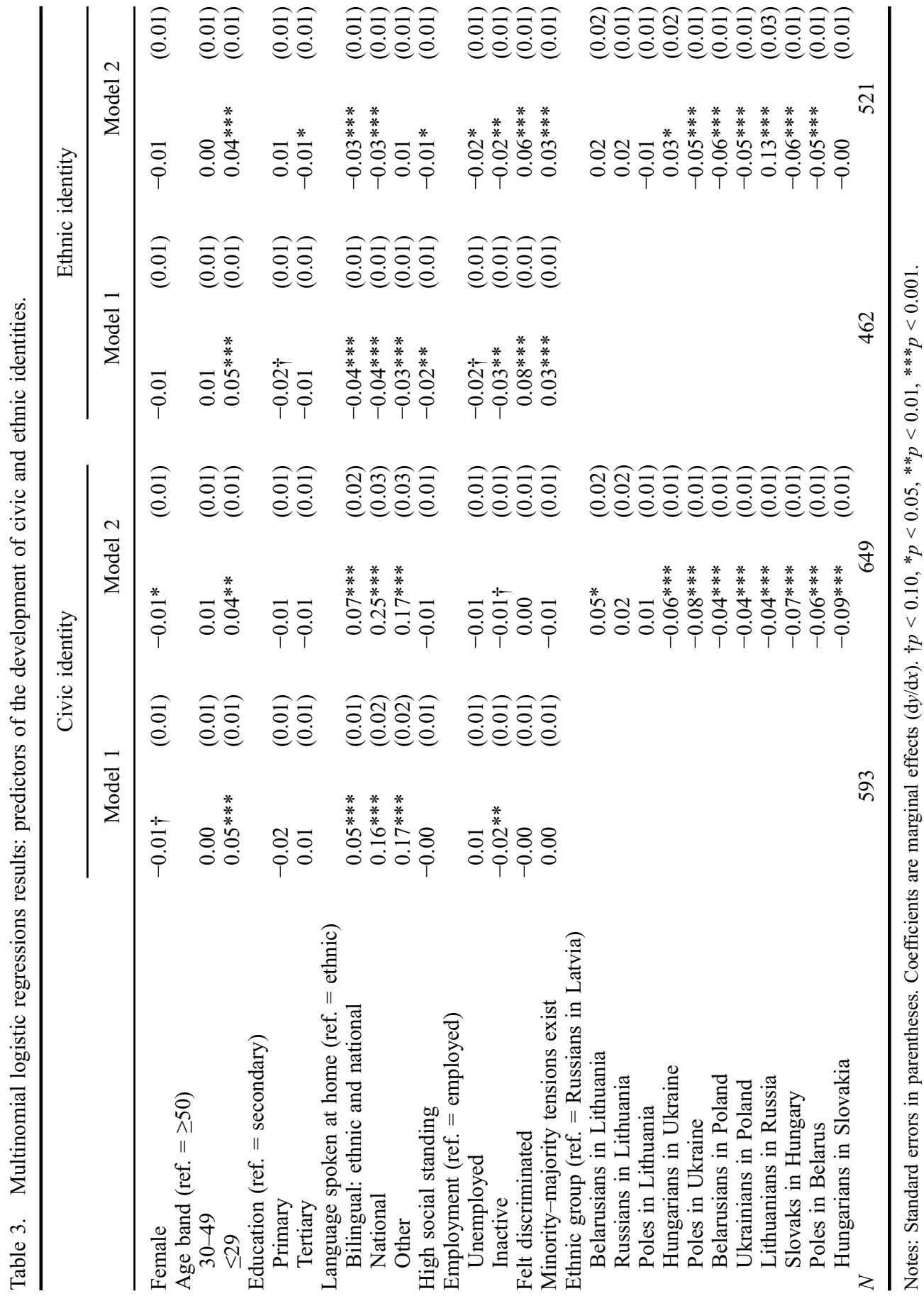




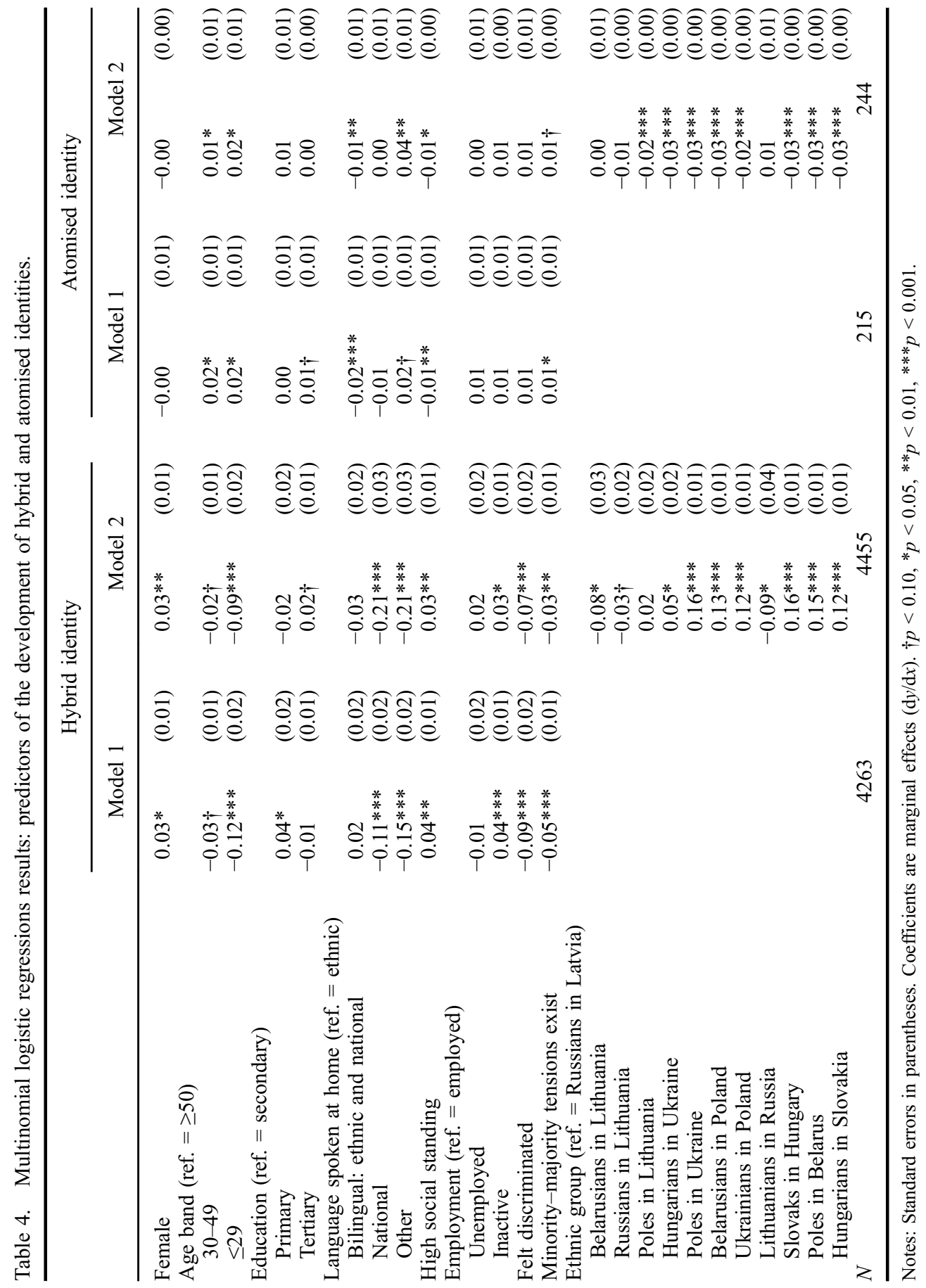


Perceptions of discrimination and minority-majority tensions are perhaps conditions with the greatest impact on identity among minority groups. Empirical evidence suggests that both the perception of discrimination and minority-majority tensions make minorities more attached to their ethnic identity and less likely to adopt a hybrid identity (Tables 3 and 4). These results confirm earlier findings (Harff and Gurr 2004; Verkuyten 2008; Coppieters 1998) that group discrimination and intergroup tensions increase ethnic attachment among kin people. Overall, the results show that discrimination and interethnic tensions pose a major integration risk for the development of cohesive multicultural societies in the CEE region.

When observing the effects of minority groups on identities, four patterns of impact are identified. The first pattern consists of those minorities who, as a group, are less likely to exhibit civic, ethnic or atomised identities while being more prone to show a hybrid identification. With Russians in Latvia as the reference group, the following minorities are in this category: Poles in Ukraine, Belarusians and Ukrainians in Poland, Slovaks in Hungary, Poles in Belarus and Hungarians in Slovakia. This path, which is dominant in our sample, provides empirical evidence to support the idea of the integration of these minority groups in the national realm of the hosting nation. The second pattern, represented by Lithuanians in (Kaliningrad) Russia and Hungarians in Ukraine, shows a significant reliance on ethnic identity. This points to an active link of the two minority groups with their nation of origin. The third pattern, which includes Belarusians in Lithuania, points to the acceptance of civic identity but the rejection of hybrid feelings. Lastly, Russians and Poles in Lithuania show nonsignificant effects in relation to all identities, with the exception of Poles who are less likely to adopt atomisation. The last two paths reflect strong policies in Lithuania that impose restrictions on nationality, the labour market and political participation for the Slavic minorities unless they demonstrate progress by means of assimilation and integration in the national realm.

These findings reveal several interesting trends. Most notably, it was observed that most minorities take on hybrid identities which are seen as a catalyst for moderation and the integration of ethnic diversity in post-communist societies. This finding provides solid empirical evidence for challenging the existing civicethnic dichotomy (Kohn 1944; Smith 1991) and the perception that the 'East' is a 'civic desert' characterised by ethnic nationalism and atomisation (Schopflin 1996). Out of 12 minorities, only two groups, Hungarians in Ukraine and Lithuanians in Russia, favour ethnic identity in relation to other identities. These two cases may be indicative of active policies which both Hungary and Lithuania pursue with respect to their diaspora in the neighbouring countries.

\section{Conclusions}

This study explores the complexity of identity feelings among 12 ethnic minorities in CEE by employing an identity typology developed by Hansen 
and Hesli (2009). By considering the strength of individuals' attachments towards their own ethnic group and the hosting nation, four identity types are identified - civic, ethnic, hybrid and atomised values. After conceptualising this typology, the analysis looked into the distribution of these identities within the sample and tested the way different identities connect with individual and group-related covariates. The evidence shows, in contrast to recent studies, that the hybrid identity is most popular among minorities in CEE. Although not empirically proven so far, this finding is not particularly surprising. The hybrid identity is an expected outcome when considering the progress towards democracy in the region. It reflects minorities' preference for civic values which democracy promotes while, at the same time, keeping close affinities with the ethnic feelings that are already traditionally found in the East. The latter aspect also suggests that ethnicity still plays a contextual role in the way CEE minorities perceive their experience with identity values. Previous research noted that minorities with hybrid identities are consistently supportive of democracy and are active in their voting behaviour (Hansen and Hesli 2009). Hence, the adopted hybrid identity by ethnic minorities is a reliable measure for the health of transition in the CEE region. With most minorities in the sample favouring the idea of hybrid values, it offers hope that ethnic minorities are able to contribute as citizens to the new democracies in the region.

This study provides empirical evidence for challenging the civic/West and ethnic/East dichotomy. Findings show that ethnic identity alone is less likely to be found in the preference of most CEE minorities, and this supports the idea that the sense of belonging to a new democratic citizenry in the region is not conditioned by the sense of belonging to the identity of the ethnic group alone but rather by the adoption of a set of hybrid values that are found to consolidate the democratic behaviour in the region.

Furthermore, it is also encouraging to find that the prevalence of atomised identities is limited in the sample. Alienation of individuals was found to be challenging for democracy, market reform and for the voting behaviour in CEE (Hansen and Hesli 2009). Being one choice among others, the troubling option of atomisation is probably balanced by competing identities in a region with dynamic values.

The analysis also tested a number of covariates in relation to civic, ethnic, hybrid and atomised identities. This study confirms the link between the bilingual use of language at home and greater civic identity. The analysis also found that discrimination and interethnic tensions are positively associated with the ethnic identity and negatively associated with hybrid feelings. At the same time, higher social standing is positively associated with more hybrid feelings and negatively associated with ethnic and atomised identities. The context of discrimination and interethnic tensions, while important, does not seem to provide complete answers as to the extent of the impact of interethnic behaviour on competing identities. Nevertheless, these findings provide new empirical 
facts for consolidating existing theories and for stimulating the further search for additional evidence.

A number of limitations to the analysis must be noted. The cross-sectional nature of the data requires caution when interpreting dynamic values such as identity feelings. With that in mind, the results of this study should be taken as snapshot evidence for the analysed period and these may change as time elapses. It is unusual to find longitudinal data that would match the wealth and the reliability of the indicators presented here. The inclusion of a large number of minority groups in the sample brings the advantage of having exclusive and informative results. Yet variations in the profiles of groups make it difficult to put forward an analysis that would speak for all of them hence preventing an overarching and conclusive model. Nevertheless, the consistency of findings across models does suggest that it is the value of competing identities that constitutes the foundation for a democratic development of CEE countries.

\section{Disclosure statement}

No potential conflict of interest was reported by the author.

\section{Funding}

Primary funding for this research was provided by the European Commission [FP7-SSH grant number 217227], Interplay of European, National and Regional Identities: Nations between States along the New Eastern Borders of the European Union (ENRI-East). Financial support from the Marie Curie Actions of the European Commission (COFUND) and Fonds National de la Recherché Luxembourg [grant number 1787100] is gratefully acknowledged.

\section{Notes}

1. The following ethnic minorities are present in this study: Russians in Latvia, Belarusians, Russians and Poles in Lithuania, Hungarians and Poles in Ukraine, Belarusians and Ukrainians in Poland, Lithuanians in Russia (the Kaliningrad enclave), Slovaks in Hungary, Poles in Byelorussia and Hungarians in Slovakia.

2. For self-rated social standing, the following question was asked: 'In [COUNTRY] today, some people are considered to have a high social standing and some are considered to have a low social standing. Thinking about yourself, where would you place yourself on this scale?'

3. This study acknowledges the fact that a strict comparability of various studies in relation to the concept of identity is difficult because of different measurements employed by authors to scale this concept.

4. For example, the evidence presented here is the inverse of that of Hansen and Hesli (2009), who found hybrid identities to be the least common among five ethnic minorities in Ukraine. 


\section{References}

Alba, R., and V. Nee. 2003. Remaking the American Mainstream: Assimilation and Contemporary Immigration. Boston, MA: Harvard University Press.

Anderson, B. 1991. Imagined Communities: Reflections on the Origins and Spread of Nationalism. 2nd ed. London: Verso.

Anthias, F. 2001. "New Hybridities, Old Concepts: The Limits of 'Culture'." Ethnic and Racial Studies 24 (4): 619-641. doi:10.1080/01419870120049815.

Bahry, D., M. Kosolapov, P. Kozyreva, and R. K. Wilson. 2005. "Ethnicity and Trust: Evidence from Russia." American Political Science Review 99 (4): 521-532. doi:10.1017/S0003055405051853.

Berry, J. W. 1997. "Immigration, Acculturation, and Adaptation." Applied Psychology: An International Review 46 (1): 5-34.

Bobo, L., and F. C. Licari. 1989. "Education and Political Tolerance: Testing the Effects of Cognitive Sophistication and Target Group Affect." The Public Opinion Quarterly 53 (3): 285-308.

Brown, D. 2000. Contemporary Nationalism: Civic, Ethnocultural and Multicultural Politics. London: Routledge.

Brubaker, R. 1996. "Nationalizing States in the Old "New" Europe-And the New." Ethnic and Racial Studies 19 (2): 411-437. doi:10.1080/01419870.1996.9993918.

Brubaker, R. 2004. Ethnicity without Groups. Cambridge, MA: Harvard University Press.

Cieslik, A., and M. Verkuyten. 2006. "National, Ethnic and Religious Identities: Hybridity and the Case of the Polish Tatars." National Identities 8 (2): 77-93. doi:10.1080/ 14608940600703650.

Connor, W. 1994. Ethnonationalism: The Quest for Understanding. Princeton, NJ: Princeton University Press.

Coppieters, B. 1998. "Form and Content in Soviet and Post-Soviet Nationality and Regional Policies." In Conflicting Loyalties and the State in Post-Soviet Russia and Eurasia, edited by M. Waller, B. Coppieters, and A. Malashenko, 12-33. London: Frank Cass.

Fishman, J. 1980. "Social Theory and Ethnography: Neglected Perspectives on Language and Ethnicity in Eastern Europe." In Ethnic Diversity and Conflict in Eastern Europe, edited by P. Sugar, 69-99. Santa Barbara, CA: ABC-Clio.

Fournier, A. 2002. "Mapping Identities: Russian Resistance to Linguistic Ukrainisation in Central and Eastern Ukraine.” Europe-Asia Studies 54 (3): 415-433. doi:10.1080/ 09668130220129542.

Gans, H. J. 1979. "Symbolic Ethnicity: The Future of Ethnic Groups and Cultures in America." Ethnic and Racial Studies 2 (1): 1-20. doi:10.1080/ 01419870.1979 .9993248$.

Hansen, H. E., and V. L. Hesli. 2009. "National Identity: Civic, Ethnic, Hybrid, and Atomised Individuals." Europe-Asia Studies 61 (1): 1-28. doi:10.1080/ 09668130802532894.

Harff, B., and T. Gurr. 2004. Ethnic Conflict in World Politics. Boulder, CO: Westview Press.

Hogg, M. A. 2001. “A Social Identity Theory of Leadership.” Personality \& Social Psychology Review 5 (3): 184-200. doi:10.1207/pspr.2001.5.issue-3.

Horowitz, D. 2000. Ethnic Groups in Conflict. Berkeley: University of California Press.

Huddy, L. 2001. "From Social to Political Identity: A Critical Examination of Social Identity Theory." Political Psychology 22 (1): 127-156. doi:10.1111/pops.2001.22. issue-1.

Ignatieff, M. 1993. Blood and Belonging: Journeys into the New Nationalism. New York: Farrar, Straus and Giroux. 
Inglehart, R. 1997. Modernization and Postmodernization: Cultural, Economic, and Political Change in 43 Societies. Princeton, NJ: Princeton University Press.

Janmaat, J. G. 2006. "Popular Conceptions of Nationhood in Old and New European Member States: Partial Support for the Ethnic-Civic Framework." Ethnic and Racial Studies 29 (1): 50-78. doi:10.1080/01419870500352363.

Katz, D. 1940. “The Psychology of Nationalism.” In Fields of Psychology, edited by J. P. Guilford. New York: Van Nostrand.

Kohn, H. 1944. The Idea of Nationalism: A Study in Its Origins and Background. New York: Macmillan.

Korostelina, C. 2003. "The Multiethnic State-Building Dilemma: National and Ethnic Minorities' Identities in the Crimea." National Identities 5 (2): 141-159. doi:10.1080/1460894032000124394.

Kymlicka, W. 2000. "Modernity and National Identity." In Ethnic Challenges to the Modern Nation State, edited by S. Ben-Ami, Y. Peled, and A. Spektorowski, 11-41. London: Macmillan.

Kymlicka, W. 2001. Politics in the Vernacular: Nationalism, Multiculturalism and Citizenship. Oxford: Oxford University Press.

Laitin, D. 1998. Identity in Formation: The Russian-Speaking Populations in the near Abroad. Ithaca, NY: Cornell University Press.

Laitin, D. 2000. "What Is a Language Community?" American Journal of Political Science 44 (1): 142-155.

Lam, V., and G. Smith. 2009. "African and Caribbean Adolescents in Britain: Ethnic Identity and Britishness." Ethnic and Racial Studies 32 (7): 1248-1270. doi:10.1080/ 01419870802298421.

Leach, C. W., M. Zomeren, S. Zebel, M. L. Vliek, S. F. Pennekamp, B. Doosje, and R. Spears. 2008. "Group-Level Self-Definition and Self-Investment: A Hierarchical (Multicomponent) Model of In-Group Identification." Journal of Personality and Social Psychology 95 (1): 144-165. doi:10.1037/0022-3514.95.1.144.

Miller, D. 1995. On Nationality. Oxford: Oxford University Press.

Oliver, J. E., and J. Wong. 2003. "Intergroup Prejudice in Multiethnic Settings." American Journal of Political Science 47 (4): 567-582.

Parekh, B. 2000. The Future of Multi-Ethnic Britain. London: Profile Books.

Phinney, J. S., G. Horenczyk, K. Liebkind, and P. Vedder. 2001. "Ethnic Identity, Immigration, and Well-Being: An Interactional Perspective." Journal of Social Issues 57 (3): 493-510. doi:10.1111/josi.2001.57.issue-3.

Platt, L. 2014. "Is There Assimilation in Minority Groups' National, Ethnic and Religious Identity?" Ethnic and Racial Studies 37 (1): 46-70. doi:10.1080/ 01419870.2013 .808756$.

Scheepers, P., A. Felling, and J. Peters. 1992. "Anomie, Authoritarianism and Ethnocentrism: Update of a Classic Theme and an Empirical Test." Politics and the Individual 2 (1): 43-60.

Schopflin, G. 1995. "Nationalism and Ethnicity in Europe, East and West." In Nationalism and Nationalities in the New Europe, edited by C. A. Kupchan. Ithaca, NY: Cornell University Press.

Schopflin, G. 1996. "Nationalism and Ethnic Minorities in Post-Communist Europe." In Europe's New Nationalism, edited by R. Caplan and J. Feffer, 150-170. New York: Oxford University Press.

Sekulic, D. 2004. "Civic and Ethnic Identity: The Case of Croatia." Ethnic and Racial Studies 27 (3): 455-483. doi:10.1080/01491987042000189240.

Shulman, S. 2002a. "Challenging the Civic/Ethnic and West/East Dichotomies in the Study of Nationalism." Comparative Political Studies 35 (5): 554-585. doi:10.1177/ 0010414002035005003. 
Shulman, S. 2002b. "Sources of Civic and Ethnic Nationalism in Ukraine." Journal of Communist Studies and Transition Politics 18 (4): 1-30. doi:10.1080/714003618.

Smith, A. D. 1991. National Identity. Reno: University of Nevada Press.

Ullah, P. 1987. "Self-Definition and Psychological Group Formation in an Ethnic Minority." British Journal of Social Psychology 26 (1): 17-23. doi:10.1111/ bjso.1987.26.issue-1.

Verkuyten, M. 2008. "Life Satisfaction Among Ethnic Minorities: The Role of Discrimination and Group Identification." Social Indicators Research 89 (3): 391-404. doi:10.1007/s11205-008-9239-2.

Weisberg, S. 2005. Applied Linear Regression. Hoboken, NJ: Wiley.

VICTOR CEBOTARI is currently a researcher with Maastricht Graduate School of Governance at Maastricht University. He works on issues of transnationalism and ethnic dynamics. He holds a PhD from Maastricht University.

ADDRESS: Maastricht Graduate School of Governance, Maastricht University, Keizer Karelplein 19, 6211 TC Maastricht, the Netherlands.

Email: victor.cebotari@maastrichtuniversity.nl 